\title{
3 Operatic Fantasies in Early Nineteenth-Century Psychiatry
}

\author{
CARMEL RAZ
}

In his celebrated essay on insanity in the Dictionnaire des sciences médicales (1816), French psychiatrist Étienne Esquirol marvelled at the earlier custom of allowing asylum inmates to attend theatrical productions at Charenton. Noting that these performances had often led to dangerous relapses or delirium, he reported on his own experience of taking patients to the opera:

I once accompanied a young convalescent to a Comic Opera. Everywhere, he saw his wife conversing with men. Another, after the space of a quarter of an hour, felt the heat in his head increasing - and said, let us go out, or I shall relapse. A young lady, seeing the actors at the Opera armed with sabres, believed that they were going to assail her. ${ }^{1}$

This passage exemplifies three ways in which attending the opera could exacerbate pre-existing mental conditions. The first patient experienced the performance through the prism of his obsessions, the second had a negative physical response to the venue itself, and the third was unable to distinguish between the onstage action and her own delusions.

Esquirol's account of the dangers of the opera to the mentally ill foreshadows subsequent discourses around the pathological effects of the music of Rossini, Meyerbeer, Wagner and others. ${ }^{2}$ As James Kennaway has demonstrated, the idea that music might have a dangerous influence on the nerves became increasingly popular during the early nineteenth century, reflecting not only changing medical theories of the mind-body connection but also the emergence of early romantic conceptions of music as capable of inducing sublime or dangerous physical responses. ${ }^{3}$ Echoes of this discourse played out within psychiatry as well, where

I would like to thank Annelies Andries, Tom Fogg, Céline Frigau Manning, Elina Hamilton and Nori Jacoby for their helpful comments on this chapter.

1 'J'ai conduit un jeune convalescent à l'Opéra-Comique, ajoute Esquirol ; il voyait sa femme causant avec des hommes. Un autre, après un quart d'heure, sentit la chaleur lui gagner la tète. Sortons, me dit-il, ou je vais retomber. Une demoiselle étant à l'Opéra, voyant les acteurs armés de sabres, crut qu'ils allaient se battre.' Esquirol 1816, 228-9. English text adapted from Hunt $1845,81$.

2 See Walton 2007; Kennaway 2012a; Kennaway in this volume, Chapter 14.

${ }^{3}$ Kennaway 2012a, 48. 
experiments with musical and theatrical entertainment in insane asylums became increasingly common as well as subject to debate. ${ }^{4}$

This chapter investigates the role of opera within early nineteenthcentury psychiatry. I begin by discussing the concept of opera as therapy, focusing on the Charenton asylum's notorious theatrical productions, which took place between 1805 and 1813 under the direction of the Marquis de Sade. I then survey different approaches to spectacle within the context of early nineteenth-century psychiatry, showing how physicians were divided about the potential benefits and dangers of incorporating theatrical representations into patient treatment. Finally, I present a close reading of two case histories from Peter Joseph Schneider's System einer medizinischen Musik (1835), an indispensable guide for medical students, directors of lunatic asylums, practical physicians, and unmusical teachers from different disciplines' ${ }^{5}$ The first concerns a young lady mourning the death of her lover, a Spanish tenor; the second recounts the cure of a sailor who could only communicate by singing. Situating the ambivalent depictions of opera that emerge in Schneider's accounts within the history of early nineteenth-century psychiatry, I argue that these cases reflect competing discourses about the alternately therapeutic and pathological power of music and spectacle.

\section{Opera as Therapy}

The early nineteenth century saw the gradual rise of a new 'moral treatment' of mental illness across Europe. ${ }^{6}$ Characterised by a more humane approach towards patients, 'moral' therapies focused on rehabilitation through distractions such as menial work or entertainment. Mental asylums that had recently chained their patients adopted new methods of therapeutic treatment: patients were now encouraged to enjoy the outdoors, to benefit from regular physical exercise, to read and to attend concerts. ${ }^{7}$ In place of bloodletting or purging, diversion became regarded as one of the main techniques of treatment for insanity. Music was widely

${ }^{4}$ See Raz 2017. ${ }^{5}$ Schneider 1835, vol. 1.

6 See Goldstein 1987; Dowbiggin 1991; Scull 2005; Foucault 2013; Knowles and Trowbridge 2015.

7 Notable here is Jean-Baptiste Pussin and Philippe Pinel's famous freeing of patients from their chains at the Bicêtre and later Salpétrière hospitals. See Weiner 1979. Under Esquirol, the Salpétrière would later feature concerts with some of the most renowned musicians in Paris. See Esquirol 1838, 2: 584-6. These efforts were subsequently expanded by Ulysse Trélat. François Leuret would likewise institute music classes and a patient choir at the Bicêtre. For a review of Trélat and Leuret's innovations see [unsigned] 1847b. 
understood as a positive force, and its usage in the service of therapy and diversion was recommended by both physicians and asylum directors. ${ }^{8}$ Theatre and spectacle were likewise regarded as powerful means of affecting the mind, and some early nineteenth-century doctors thought they might usefully be deployed to combat irrational obsessions and delusions. ${ }^{9}$

Philippe Pinel, a pioneer of moral treatment, discussed the advantages of ceremonies and role-playing in his influential Traité médico-philosophique sur l'aliénation mentale (1801). He praised the annual mass exorcism at Besançon, in which priests healed the possessed by means of an elaborate ritual accompanied by martial music and the sounds of cannons, and suggested that physicians likewise incorporate theatrical elements into their practice. In a famous example, Pinel described his treatment of a tailor obsessed by delusions of guilt through staging of a mock trial in which visiting physicians played the role of a government deputation. (Unfortunately, the patient had a nervous breakdown after inadvertently learning that both his trial and acquittal had been fabricated.) ${ }^{10}$

In his Rhapsodien über die Anwendung der psychischen Kurmethode auf Geisteszerrüttungen (Rhapsodies about the Application of Psychological Treatment to Mental Breakdown; 1803), Johann Christian Reil cited Pinel's example of mass exorcism in recommending the use of music and theatre to both entertain and heal the insane. He argued that every asylum should offer a theatre complete with masks, sets and stage machinery. This would allow the physician to stage scenarios reflecting the patient's own condition; such dramatic enactments would allow patients to engage with, and ultimately resolve, their fears. ${ }^{11}$

${ }^{8}$ Roller $(1831,199-203)$ summarises contemporary approaches to music therapy and provides the reasoning of sixteen major psychiatrists in support of music.

9 See Goldstein 1987, 87. For more on opera and spectacle in early nineteenth-century Paris see S. Williams 2003; Hibberd 2013; Andries 2018.

10 'The principal part was assigned to the eldest and gravest of them, whose appearance and manners were most calculated to command attention and respect. These commissaries, who were dressed in black robes suitable to their pretended office, ranged themselves round a table and caused the melancholic to be brought before them. One of them interrogated him as to his profession, former conduct, the journals which he had been in the habits [sic] of reading, and other particulars respecting his patriotism ... In order to make a deep impression on his imagination, the president of the delegates pronounced in a loud voice the following sentence ... "It is, therefore, by us declared, that we have found the said Citizen a truly loyal patriot; and, pronouncing his acquittal, we forbid all further proceedings against him."' Pinel 1806, 227.

11 Reil 1803, 209-10: 'Ich bemerke bloss im Allgemeinen, dass jedes Tollhaus zum Behuf ihrer imposanten Anwendung und zweckmässigen Zusammenstellung ein für diese Zwecke besonders eingerichtetes, durchaus praktikabeles Theater haben könnte, das mit allen nöthigen Apparaten, Masken, Maschinerien und Dekorationen verfehen wäre. Auf demselben müssten 
The leap from spectacle to therapeutic theatre was made in the early 1800s by Abbé François de Coulmier, director of the Charenton lunatic asylum, and his head physician, Jean-Baptiste Gastaldy. ${ }^{12}$ Beyond the resolution of irrational fears, Coulmier claimed that dramatic performances also had the potential to 'awaken the minds of hapless people completely lost in the cruel illness of dementia'. ${ }^{13}$ For nearly a decade, plays, comic operas and ballets were produced on a monthly basis at the institution, which featured a spacious auditorium complete with a stage, orchestra pit, tiered stalls and a director's box. These semiprofessional productions, which typically featured patients acting alongside local actors, musicians and dancers, attracted audiences from all over Paris. ${ }^{14}$

Contemporary accounts provide intriguing glimpses of Charenton's theatrical spectacles (I use this term in the nineteenth-century sense of the word to refer to stage performances of all kinds including plays, operas and ballets). The actress Flore Corvée recalled visiting in 1813 in order to see opéra comique star Jeanne-Charlotte Saint-Aubin perform alongside the patients. The programme included Molière's five-act play Le Dépit amoureux (1656) followed by Dalayrac's comic opera, Les Deux petits savoyards (1789), and new verses by the asylum's most infamous inmate, the Marquis de Sade. ${ }^{15}$ Corvée described each of the patients in detail, evaluating their success (or failure) in performing their assigned roles. Some of them he deemed completely capable of fulfilling their duties, and Corvée had particular praise for a beautiful black-haired patient who sang new verses by de Sade. ${ }^{16}$ Others were clearly troubled, however, such as the actor who suddenly threw his wig into the prompter's box. ${ }^{17}$ Corvée seemed secretly thrilled to have met de Sade himself, whom she compared to a monster in a cage. ${ }^{18}$

Claude de Rochefort, a playwright and vaudeville actor, had a similar reaction when encountering de Sade at the Charenton production of

die Hausofficianten hinlänglich eingespielt seyn, damit fie jede Rolle eines Richters, Scharfrichters, Arztes, vom Himmel kommender Kugel, und aus den Gräbern wiederkehrender Todten, nach den jedesmaligen Bedürfnissen des Kranken, bis zum höchsten Grad der Täuschung vorstellen könnten. Ein solches Theater könnte zu Gefängnissen und Löwengruben, zu Richtplätzen und Operationsfälen formirt werden.'

12 For more on the Charenton theatre see Tucker 2007. In 1964, Peter Weiss wrote a play set in the Charenton in 1808, entitled The Persecution and Assassination of Jean-Paul Marat as Performed by the Inmates of the Asylum of Charenton under the Direction of the Marquis De Sade.

13 Archives Nationales, F15 1946. Letter from Coulmier to Emperor Napoleon, 1811, as quoted in Murat 2014, 99.

14 Esquirol 1838, as translated in Earle 1841, 141-2. ${ }^{15}$ Corvée 1845, 2:172-8.

${ }^{16}$ Corvée 1845, 2:182. ${ }^{17}$ Corvée 1845, 2:181. ${ }^{18}$ Corvée 1845, 2:175-6. 
Marivaux's three-act comedy Les Fausses confidences (1737). Having sat next to a charming older gentleman at dinner, Rochefort was stunned to discover that this was in fact the author of the infamous novel Justine. ${ }^{19}$ The poet Jean de Labouïsse reported on a Charenton performance of de Desmahis's comedy L'Impertinent, in which de Sade ably performed the lead role. Labouïsse described him as 'cet infâme scélérat' (this infamous scoundrel) and wondered whether it was right that he was allowed to distract himself from the memory of his crimes. ${ }^{20}$

The Charenton's theatre also generated controversy in the Germanspeaking world. In a report on Parisian lunatic asylums from 1808, August Schweigger gave his impressions of a Charenton performance of the comedy Le Sourd, ou l'Auberge pleine (1793) by Desforges that featured incidental music and a small ballet; this was followed by Grétry's one-act comic opera Le Tableau parlant (1770). ${ }^{21}$ Schweigger noted that such productions appeared to have therapeutic potential but regarded comedies involving romantic intrigue as too stimulating for invalid actors and spectators. $^{22}$ The physician Carl Andrée took a more extreme view, criticising the Charenton theatre for forcing lunatics, who were already alienated from themselves, to inhabit yet another persona in front of a curious public. $^{23}$

There was significant dissent within the Parisian medical community regarding the therapeutic benefit of such performances. Gastaldy's successor as head physician, Antoine-Athanase Royer-Collard, was adamantly opposed to theatrical productions, and Coulmier's intimacy with de Sade, who had honoured him with an allegorical masque praising the therapeutic use of theatre, soon proved to be a liability. ${ }^{24}$ In a letter dated 2 August 1808, Royer-Collard complained to Joseph Fouché, Minister of the Police, that Coulmier had a 'theatre erected for the performance of comedies and did not think of the harmful effects of such a tumultuous proceeding upon the mind. De Sade is the director of this theatre. ${ }^{25}$ Royer-Collard's efforts were supported by a critical assessment of the Charenton by Hippolyte de Colins in 1812. Colins was appalled at de Sade's participation in the hospital's dramatic productions, and attacked the Charenton for exploiting its patients as 'objects of curiosity in an amphitheatre before the avid gaze

\footnotetext{
19 Rochefort-Luçay 1863, 241. ${ }^{20}$ Labouïsse 1827, $154 .{ }^{21}$ Schweigger 1809, 19-23.

22 Schweigger 1809, 11-12, 26. ${ }^{23}$ Andrée 1810, 220.

24 In La Fête de l'amitié, an allegorical play, de Sade extols Coulmier while advocating for the power of theatre to cure the mad.

25 Cited and translated in I. Bloch 2010, 170.
} 
of a shallow, inconsequential and sometimes nasty public'. ${ }^{26}$ In 1813 , the Ministry of the Interior banned all theatrical performances at the Charenton. ${ }^{27}$

The loudest voice in response to the Charenton scandal came from the aforementioned Esquirol, who would succeed Royer-Collard as chief physician of the institution in 1825. In a series of works published between 1816 and 1838, Esquirol strongly condemned the theatrical productions at the asylum, noting that they were useless at best and dangerous at worst. ${ }^{28} \mathrm{He}$ disagreed with the very premise of enclosing patients 'for three hours in a confined, heated and noisy place, where everything tended to produce headaches'. ${ }^{29}$ Crucially, Esquirol consistently advocated for a separation between opera and concert music, stating that the former was dangerous because it exalted the imagination and passions, whereas the latter could be 'a valuable remedial agent, particularly in convalescence. ${ }^{30}$ His separation between music and spectacle was subsequently adopted by Gottlob von Nostitz und Jänkendorf, who cited the Charenton episode in dismissing all theatrical productions as dangerous while reporting on weekly concerts performed by patients at his asylum for the insane at Sonnenstein (1829). ${ }^{31}$

In spite of Esquirol's considerable stature in the field, his distinction was contested by a number of physicians. Only a year after Esquirol's initial excoriation of the Charenton theatricals in the Dictionnaire des sciences médicales, François Fodéré (1817) responded that this critique of the Charenton productions had not convinced him that spectacle was categorically dangerous for patients. ${ }^{32}$ Fodéré continued to recommend that every insane asylum be outfitted with a hall dedicated to spectacles and concerts, as well as baths, gardens and fountains. ${ }^{33}$ A similar opinion was held by Viennese psychiatrist Bruno Görgen (1820), who encouraged his patients to attend both concerts and plays. ${ }^{34}$ Belgian psychiatrist Joseph Guislain (1826) also refused to rule out the possibility that theatrical representations could be of some therapeutic use. ${ }^{35}$

${ }^{26}$ Hippolyte de Colins, Notice sur l'Etablissement consacré au traitement de I'aliénation mentale, établi à Charenton près Paris, excerpted in Pinon 1989, 77.

27 I. Bloch 2010, 171.

28 These writings include his article 'Folie' in Dictionnaire des sciences médicales (1816), the Rapport statistique sur la Maison Royale de Charenton (1818), and his monograph Maladies mentales et des asiles d'aliénés (1838). Esquirol reused the same text in all three of these works with minor alterations.

29 Translation adapted from Hunt 1845, 1:80. ${ }^{30}$ Hunt 1845, 1:81.

31 Nostitz und Jänkendorf 1829, 1:336-41. $\quad{ }^{32}$ Fodéré 1817, 2:216. $\quad{ }^{33}$ Fodéré 1817, 2:218.

34 Görgen 1820, 27. ${ }^{35}$ Guislain 1826, 277. 
In Die Irrenanstalt nach allen ihren Beziehungen dargestellt (A Portrait of the Madhouse and All Its Dealings; 1831), Christian Roller included a fourpage review of contemporary opinions on the use of music and theatre, listing its pros and cons alongside the reasoning each physician provided for his view. ${ }^{36}$ Roller's final tally comes out even: seven physicians against (including himself), and seven in favour. ${ }^{37}$ This shows how, in the early 1830s, spoken and sung theatre had an ambiguous status within the psychiatric community. Some physicians argued that it was explicitly dangerous for the mentally ill while others regarded it as a beneficial distraction. There were distinguished supporters on both sides of the argument, and the issue remained largely unresolved. In what follows, I discuss the reverberations of this debate within contemporary music therapy, focusing on two case histories reported by Schneider. As I will show, the construction of his diagnoses and cures interacts with both approaches in a complex fashion. As such, they shed light on the ways in which discourses around opera and psychiatry around 1835 were imbricated with early romantic fantasies about music, gender, class and mental illness.

\section{Medico-Operatic Case Histories}

At nearly 750 pages, Schneider's System einer medizinischen Musik (1835) combines medicine with music history, theory and aesthetics. It contains abundant references - in German, Latin, Greek, French and English - to physicians and musicians from antiquity as well as the author's contemporaries. Teetering between the ancient tradition of compiling sources on the effects of music and the emerging field of modern psychiatry characterised by experimental methods, the book ends with the detailed case histories of Lina and Bals, two patients suffering from 'musical afflictions. ${ }^{38}$ Mirroring a longstanding cultural practice of situating music between entertainment and spiritual edification, Schneider aligns arias and recitative with sickness, and religious chorales and work songs with health. In both accounts, he himself cures his

36 Roller 1831, 203-6.

37 According to Roller, the doctors Reil, Langermann, Heinroth, Guislain, Görgen, Schweigger and Rush are in favour of theatrical spectacle, and the doctors Esquirol, Royer-Collard, Haldat, Nostitz und Jänkendorf, Andrée and Frank are against it.

38 Schneider lived near Bonn for the duration of his short life, and should not be confused with his namesake and contemporary, the renowned physician Peter Joseph Schneider (1781-1871) from Baden, who also authored numerous medical texts. François-Joseph Fétis conflates them in his Biographie universelle (1835-44, 8:126). 
patients of their operatic excesses, allowing them to resume their designated place within the social order.

Schneider recounts a research trip in the summer of 1831 to the Netherlands accompanied by one Dr Zober, a friend and colleague. Their first patient is Lina, the nineteen-year-old daughter of wealthy Dutch merchants who had remained in an intractable melancholy for over two years. Upon questioning her parents, Schneider establishes that her condition had been caused by the death of Antonio, her father's Spanish apprentice, whom she had secretly loved. The youth had unexpectedly died after contracting a nervous fever, plunging Lina into a depressive state that Schneider diagnoses as melancholia attonita. $^{39}$

Lina and Antonio had met during weekly house concerts put on by the girl's uncle, an accomplished amateur musician. These performances featured works for male choir, as well as the occasional instrumental piece or opera aria. Antonio, Schneider learns, was 'a tenor possessing such qualities as man and musician, in spirit and body alike, as to command the attention of both sexes'. ${ }^{40}$ Proficient also on the mandolin, his performances at the house concerts had 'enchanted the daughter of the house through the enticing singing and playing summoned out of his Spanish throat and fingers' ${ }^{41}$

Lina's parents insist that Antonio had been unaware of her feelings and that a relationship between the two was unthinkable. However, Schneider doubts their account: he discovers that the youth had regularly performed the romance from Daniel Auber's Fra Diavolo, 'Pour toujours, disait elle, je suis à toi', and the cavatina from Auber's La Muette de Portici, 'Ferme tes yeux, la fatigue t'accable'. In a footnote, he includes the texts of both in German, and muses, 'could these words, passionately and expressively sung by the powerful tenor of our Spaniard, fail to make their intended impact? ${ }^{32}$

Alongside her depression, Lina exhibited minor physical distress, and her period had been absent for nine months. Schneider decides on two courses of treatment: one physical, to target the body; the other musical, to

39 The term comes from Johann Jacob Müller's De melancholia attonita raro litteratorum affectu (1741). According to Müller, this was a specific species of religious melancholy, in which one is rendered first depressed, then for a long time mute, immobile, senseless, with limbs almost rigid, emaciated, with very few movements left to him, e.g. with the result that he swallows only immediately after food has been thrust into his mouth and blinks when fingers have been moved before his eyes, and sometimes sleeps'. Müller, as translated in Rubin 2004, 177.

${ }^{40}$ Schneider 1835, 2:255. ${ }^{41}$ Schneider 1835, 2:266. ${ }^{42}$ Schneider 1835, 2:258. 
cure the mind. After considering and rejecting a course of emetics - copper sulphate dissolved in cherry laurel water - he decides to prescribe a hydropathic treatment, of the kind much in vogue during the $1830 \mathrm{~s}^{43}$ The water cure soon vanquishes all of Lina's physical symptoms, with the exception of her absent menses.

Schneider maintains that Lina's soul requires a different approach: a 'purely psychic treatment, to consist of ethereal sounds [ätherische Klängen]'. ${ }^{44}$ He therefore decides to stage a musical intervention with the aid of the girl's family, accompanied by himself on the aeolodicon, an early type of harmonium. The event takes place in the evening: Lina is seated upon the sofa in her bedroom, illuminated by a weak lamp. Dr Zober is concealed in a corner, observing her, and Schneider joins her uncle, father and a musical friend in an adjacent room. Schneider decides to begin the cure with his own improvised prelude on the aeolodicon, followed by one of the patient's favourite chorales sung in four voices. He hopes the former will brighten the patient's mood and amplify her receptivity, so that the latter can awaken dormant memories. Schneider assigns the melody to the uncle, who possesses a powerful tenor voice, and asks the other singers to sing softly. The cure goes according to plan:

I began to improvise in $\mathrm{E} b$ minor, one of the keys corresponding to deepest melancholy. Softly, and so, swelling to the strongest fortissimo, and then decreasing to a moderate piano, giving way to pure triads, and thus through the various voicings and turns of the harmony. At the beginning of the third crescendo and then immediately after, Zober observed the patient gasp and shiver in what appeared to be a complete seizure of her full nervous system. Yet she remained dumb and immobile. I preluded to Gb major and began the chorale, swelling from the lightest breaths and back again, and then the quartet began to sing the first few words. We were not yet at the end, when clearly, supported softly by the choir, the tenor took the melody. Suddenly, the invalid cried loudly, 'O! Antonio! Antonio!' (the name of the Spaniard); and began to cry so deeply that we had to stop our chorale; the young girl had to be carried to bed. Upon illuminating the room we observed the good news that upon crying 'O! Antonio', at once her monthly flow had suddenly begun, as the floor was thoroughly soiled by it. ${ }^{45}$

Schneider muses that ' $[o]$ ne should almost believe that the soul had been nourishing itself from this blood, but was now returned to its old domain. Was this due to the ethereal sounds? ${ }^{46}$ In closing, Schneider recommends

\footnotetext{
43 Schneider goes into considerable detail regarding the construction of a shower in the greenhouse, as well as her dietary and bathing schedules. See also Steward 2002.

44 Schneider 1835, 2:265. ${ }^{45}$ Schneider 1835, 2:267-8. ${ }^{46}$ Schneider 1835, 2:268.
} 
that the girl travel abroad or visit the home of a country pastor for convalescence, and that her parents find her a groom as soon as she recovers. The case ends with a postscript telling that Lina married one of her father's apprentices shortly after and had a child.

Let us now turn to Schneider's second study. This relates to Bals, a 'coarse and uneducated' sailor, thirty-three years of age, who can only communicate through singing. ${ }^{47}$ Known today as psychogenic dysphonia, this condition is characterised by an alteration of the voice due to mental rather than physical causes. ${ }^{48}$ The origin of Bals's affliction soon emerges: the sailor had moonlighted as a smuggler. Ambushed by the Ostend border police, he beat one of the officers so badly that the man later died. Bals was subsequently sentenced to a long prison term. Upon his release, he appeared on the cusp of a nervous breakdown, obsessed with 'morbid ideas concerned not only with pride, but also with greed, and especially with an exaggerated fear of the future. ${ }^{49}$ Most peculiar, however, was the following symptom:

Whenever a physician attended the patient, (and there were many of these [visits],) the patient welcomed them all with a strange song: 'A good day sir, my good doctor, you are well, that pleases me, I was always thinking of you, help me.' The patient performed these and comparable speech-songs in the form of a ghastly recitative in a terrible voice; and all the questions that were put to him were also answered in the form of a recitative, singing, or rather howling. ${ }^{50}$

As this passage illustrates, Bals is completely unable to control his vocal production. Schneider notes that a local physician had initially obtained some improvement through regular bloodlettings in conjunction with the counsel of an experienced preacher. However, this success was only temporary, and the sailor had since relapsed. Schneider thus offers to conduct a musical cure.

Schneider begins by preparing the musical performance. He gathers a group of local musicians - two horn players, two clarinets, a bassoonist, a trombonist and a drummer - and four sailors, and decides that they will sing 'Matrosen, die Anker gelichtet', a song composed in 1823 by Christian Pohlenz to a text by Wilhelm Gerhard. Schneider asks the sailors to sing this piece in their 'Dutch dialect', and instructs the musicians to accompany and the drummer to play 'more softly than usual'. 51

\footnotetext{
47 Schneider 1835, 2:287. $\quad{ }^{48}$ For further reading see Butcher, Elias and Cavalli 2007.

49 Schneider 1835, 2:288. ${ }^{50}$ Schneider 1835, 2:289. ${ }^{51}$ Schneider 1835, 2:291.
} 
Next Schneider embarks on the treatment. He visits Bals and inquires after his health. The sailor sings in response: 'Sir, I know not who you are, but I remain who I am! Trillerum da da! etc. If I am damned, then I am damned. But I did not beat him to death. ${ }^{52}$ Schneider then invites the band into the room, and asks them to perform their ditty. The effect of the music upon the patient is striking:

The eyes of our patient sparkled, his entire body jerked, he moved his hands and feet, and joined in the singing with a terrifying energy. When we were at the end, he called Da Capo!, and jumped from his bed and joined his sailor fellows. We then sang the second verse, after which his wife distributed brandy, which he drank. After this I requested a waltz to be played, and he grasped his wife, kissed and embraced her (for the first time since his sickness) and danced with her, in such a furious way that the sailors, one after the other, had to replace the poor woman. In the end he was so damp and exhausted, that he fell on his bed and slept. ${ }^{53}$

The merry sounds of Schneider's band seem to galvanise the sailor: his eyes sparkle, his entire body twitches, he moves his limbs and joins in the singing with an energy that Schneider describes as terrifying (schauderhaft) - the same adjective he initially used to describe the quality of the sailor's recitative. The power of music and dance restore Bals's vital forces to the point that the next day he is glimpsed chopping firewood in the courtyard. No longer emasculated by the uncanny singing voice, he can now resume his position as provider and head of the household. After six months, Schneider writes, Bals had fully recovered his health and returned to sea.

While both of these cases have successful outcomes, they are plagued by a number of strange inconsistencies. Schneider dates his trip to July 1831, and informs us that Lina had been depressed for two years. Antonio would thus appear to have died in 1829 , yet Lina recalls that he frequently sang an aria from Fra Diavolo, which only received its premiere in 1830. There are discrepancies in Bals's case history as well. An uneducated sailor is inexplicably fluent enough in musical terminology to cry out ' $D a$ Capo!' at the end of the performance. Freshly released from jail after a lengthy prison sentence, he is apparently familiar with a recently composed German art song, a piece so popular that street musicians in the Netherlands have added it to their repertoire in Dutch. Moreover, in 1831, Ostend, the town in which Bals's case transpires, was already part of Belgium, rather than the Netherlands. ${ }^{54}$

52 Schneider 1835, 2:291. ${ }^{53}$ Schneider 1835, 2:292.

54 I thank Annelies Andries for bringing this to my attention. 
There is a remarkable explanation for these irregularities. It seems that the medical details of both case histories were plagiarised verbatim from System der höhern Heilkunde für Ärzte, Prediger und Erzieher (System of Higher Healing for Physicians, Preachers and Educators; 1826), a medical text aimed at both physicians and religious clergy published by the physician and theologian Ernst de Valenti nearly a decade earlier. ${ }^{55}$ De Valenti's first case history, the source for Schneider's account of Bals, describes the treatment of a thirty-five-year-old German peasant who had lost his voice following a fatal encounter with a forest ranger who had caught him poaching. Jailed for a lengthy period for beating the ranger to death, the man emerges with an obsessive mania manifesting in the compulsion to communicate by singing in a ghastly recitative. De Valenti treats him with bloodlettings combined with frequent evangelical counsel, some of which he reproduces in his book. The man makes steady progress, and occasional relapses are treated with the herbal sedative belladonna. Four weeks later, he is cured. ${ }^{56}$

De Valenti's second report, the basis of Schneider's account of Lina, concerns a twenty-year-old peasant woman who has been suffering from melancholia attonita for over a year. The causes of this sickness are unclear, but her parents inform him that she had previously complained of bone pain and that her menses had stopped. As Schneider would claim later, de Valenti treats her with a course of emetics consisting of a gram of copper sulphate dissolved in cherry laurel water. The first dose brings about immediate improvement, and over the next few months her menses return, her mood improves and her health is restored. ${ }^{57}$

It appears, then, that Schneider grafted de Valenti's case histories onto an elaborately detailed course of musical treatment - the originals feature no music whatsoever. He takes some care to cover his tracks, reversing the order of the case histories, employing a synonym here and there, as well as altering the geographical location, occupation, age and social class of his

55 This finding transpired by chance: while translating the second case study, I stumbled across an unfamiliar hat: Bals wears a 'dirty Baschkirenmütze pulled over his ears'. By sheer luck, I come across perhaps the only word that could have led me to Schneider's secret: a variant spelling of the more common Baskenmütze specific enough to conjure up de Valenti within the search results, while hardy enough to have withstood Google Books' capricious Fraktur optical character recognition. It should be noted that the diagnostic questions Schneider poses to Lina's parents in the first case history incorporate substantial verbatim text from Handbuch der Pastoral-Medicin für christliche Seelsorger (1823) by the physician and chemist Christian Schreger. These questions are presented as Schneider's own. Compare Schneider 1835, 2:251-2 to Schreger $1823,462-3$.

56 de Valenti 1826, 1:95-103. ${ }^{57}$ de Valenti 1826, 1:104-7. 
Table 3.1 A comparison of de Ernst de Valenti's and Peter Schneider's reports of the patient's speech

\begin{tabular}{|c|c|c|}
\hline $\begin{array}{l}\text { de Valenti, System der } \\
\text { höhern Heilkunde 1: 97-98 }\end{array}$ & $\begin{array}{l}\text { Schneider, System einer } \\
\text { medizinischen Musik 2: } \\
\text { 288-91 }\end{array}$ & $\begin{array}{l}\text { Schneider, System, my } \\
\text { translation }\end{array}$ \\
\hline $\begin{array}{l}\text { Willkommen Herr Doktor, } \\
\text { ich freue mich Sie wohl } \\
\text { zu sehen, ich habe } \\
\text { immer an Sie gedacht, } \\
\text { machen Sie mich doch } \\
\text { wieder gesund. }\end{array}$ & $\begin{array}{l}\text { En guten Tag Herr, mein } \\
\text { guter Herr Doktor, Sie } \\
\text { sind wohl, das freu't } \\
\text { mich, dacht' ich doch } \\
\text { immer an Sie, helfen Sie } \\
\text { mir. }\end{array}$ & $\begin{array}{l}\text { A good day sir, my good } \\
\text { doctor, you are well, that } \\
\text { pleases me, I was always } \\
\text { thinking of you, help } \\
\text { me. }\end{array}$ \\
\hline $\begin{array}{l}\text { Mein lieber Herr Doktor, } \\
\text { ich wollte gern anders } \\
\text { reden, ich kann aber } \\
\text { nicht, ih muss singen. }\end{array}$ & $\begin{array}{l}\text { Mein liebes Doktor'chen, } \\
\text { gerne wollt ich anders } \\
\text { reden, ich kann doch } \\
\text { nicht anders, ich muss } \\
\text { nun einmal singen. }\end{array}$ & $\begin{array}{l}\text { My good doc, gladly } \\
\text { would I speak differ- } \\
\text { ently, but I cannot, I } \\
\text { must first sing. }\end{array}$ \\
\hline & $\begin{array}{l}\text { Herr, Sie kenn' ich nicht, } \\
\text { wer sie sind, wie Sie sind, } \\
\text { so bleib ich doch, wie ich } \\
\text { bin! Trillerum da da! u.s. } \\
\text { w. Bin ich verdammt, } \\
\text { nun dann bin ich } \\
\text { verdammt. Ich hab'n } \\
\text { aber nicht todt } \\
\text { geschlagen! }\end{array}$ & $\begin{array}{l}\text { Sir, I know not who you } \\
\text { are, or what you are, } \\
\text { thus I too remain what I } \\
\text { am. Trillerum da da! } \\
\text { etc. If I am damned, } \\
\text { then I am damned. But I } \\
\text { did not beat him to } \\
\text { death! }\end{array}$ \\
\hline
\end{tabular}

patients. He even gives them first names, in contrast to de Valenti, who reports on two anonymous German peasants. Table 3.1 is an example of corresponding passages in de Valenti and Schneider's versions. Beyond the consistent rearrangement of the word ordering, there are hardly any differences between de Valenti's transcription of his patient's words and the remarks that Schneider assigns to Bals.

As Table 3.1 shows, de Valenti and Schneider's first two quotations correspond perfectly. But the third response, which has no correlate in the original text, is markedly different in content and tone: the patient appears not to recognise his physician, and addresses him as 'sir' rather than 'doctor'. It also includes a denial of guilt and acceptance of damnation, details reflecting Schneider's own lively imagination. Most striking, however, is the addition of the melodic vocalisation 'trillerum da da!' This embellishment suggests that Schneider misunderstood the symptoms described by de Valenti: he appears to believe the man was singing a musical phrase, rather than speaking in a singsong voice. 
Knowing that Schneider invented all of the musical details of these accounts puts the information he provides in a new light. We can regard his reports as an expression of the author's fantasies about the healing power of music; a calculated attempt to install music as a bona fide medical tool capable of restoring the health of lovelorn maidens and rough-hewn sailors alike. The correlations drawn between sickness and health, opera and chorales, and the carnal tenor and ethereal harmonium, are now exposed as the author's dreams about the power of music operating on the mind and body. Finally, we can see the calculated extent to which these cases were designed to argue in favour of music-theatrical treatment.

Throughout Lina's case history, Schneider uses opera to provide implicit commentary upon the situation at hand. The character of Antonio embodies a conception of an operatic tenor as seductive, foreign and dangerous: a 'Spanish throat and fingers ${ }^{\text {'58 }}$ seducing by means of French words and music. Adhering to operatic conventions regarding the habits of Spanish lovers, Antonio accompanies his serenades on a mandolin. ${ }^{59}$ The perilous effects of these sounds leave a fatal mark upon Antonio's person: shortly after capturing Lina's heart, he dies of a nervous fever, a fate reflecting the social transgression implicit in the forbidden attachment of a wealthy merchant's daughter and a poor apprentice. Their courtship, scandalously conducted within the family home despite the watchful eyes of the girl's parents and uncle, relies solely upon the sensuous sounds of opera arias. Antonio's sudden death from nervous fever fails to restore social order, and Lina likewise contracts a debilitating nervous malady.

In spite of the moralising undertones of this situation, Schneider's selection of Antonio's repertoire displays a surprising compassion for the lovers' plight. In the aria from Fra Diavolo, the impoverished but nobleminded soldier Lorenzo vows his eternal love for the innkeeper's daughter Zerline, who at this point in the opera will be forced to wed the wealthy Francesco. A similar sensitivity appears in the aria from La Muette, during which the fisherman Masaniello comforts his sister, the mute Fenella, who has been seduced and abandoned by the son of the Viceroy of Naples. Masaniello promises his exhausted sister that he will watch over her as she sleeps. If during the initial house concerts Lina and Antonio were akin to Fra Diavolo's star-crossed lovers, by the time Schneider enters the picture

58 Schneider 1835, 2:256.

59 As a comparison, Count Almaviva serenades Rosina with a mandolin in Paisiello's Il barbiere di Siviglia (1782), and Don Giovanni serenades Elvira's maid with the same instrument in Mozart's Don Giovanni (1787). In Grétry's L'Amant jaloux (1778), which is set in Spain, French officer Florival serenades 'Léonore' / Isabelle with a mandolin. 
they have transformed into La Muette de Portici's brother and sister. Antonio watches over Lina from the afterlife, while she has adopted the traits ascribed to Fenella: she is mute and half asleep. ${ }^{60}$ It therefore evidences medical knowledge by way of a musical narrative.

Schneider's account of the staging of his musical cures likewise evokes an operatic performance. He schedules the musical cure in the evening, giving it the flavour of a theatrical performance. Lina sits on a sofa in a dimly lit room. A minor character - Schneider's friend, the silent Dr Zober - is hidden in a dark corner of the chamber as an observer. There are other roles in this musical drama: Schneider casts Lina's uncle as Antonio, rather than her father, who sings a supporting line within the chorale, probably to avoid the implication of any kind of incestuous substitution. Like offstage musicians, the soloist, chorus and instrumentalist are concealed in an adjacent room. This description provides us with the exact layout of the event, ranging from the lighting to the distribution of characters and musicians.

The musical parameters of this cure, particularly the selection of instrument and key, have explicit affective associations developed earlier in System einer medizinischen Musik. Schneider's account of modulating from $\mathrm{E} b$ minor to $\mathrm{G} b$ major is charged with symbolic meaning drawn from Christian Schubart's storied key characteristics. In Ideen zu einer Ästhetik der Tonkunst (Reflections on an Aesthetics of Music; 1806), Schubart claims that $\mathrm{E} b$ minor represents 'feelings of anxiety and deep turmoil of the soul; of suppressed despair, of blackest melancholy, of the gloomiest state of mind. Every fear, every quake of the shuddering heart is aired.' By contrast, Gb major represents 'triumph over difficulty, breathing freely having climbed a hill. Echo of a soul that has struggled valiantly and conquered. ${ }^{61}$ It would seem Schneider's employment of these keys as reference points models the affective transition that he intends to induce in Lina.

The selection of the aeolodicon is likewise laden with association. ${ }^{62}$ Invented around 1810 by Gabriel-Joseph Grenié in France and independently in Germany a few years later, this was a new instrument, distantly

60 Schneider depicts Lina as 'partly stupefied and partly sensible, mostly mute, she sat the whole day on the sofa, half of the time dazed [stauend] and the other half musing, staring straight ahead'. Schneider 1835, 2:251. For more on the early nineteenth-century medical context of Fenella's mutism see Smart 2004, 32-68.

61 Schubart translated in Macdonald 2008, 163.

62 As I have shown elsewhere, Schneider's selection of the aeolodicon also aligns with the contemporaneous practice of using this instrument to treat predominantly young female patients displaying the (frequently hysterical) symptoms of catalepsy. See Raz 2014. When 
based on the harmonium. ${ }^{63}$ Because Schneider assumed his readers might be unfamiliar with its sounds, he reprints a description of the instrument from Gustav Schilling's Universal-Lexicon der Tonkunst (1834) in full, which includes the following:

The aeolodicon is an instrument whose tone is produced when air or wind is conveyed over freestanding metal pipes ... [It] affords the creation of very regular and well-balanced crescendo and decrescendo effects, according to the rate at which the air in the bellows flows over the tongues. It has six full octaves, and its tone is certainly pleasant in certain respects (in the high octaves it resembles the flute and clarinet, in the middle the horn, and in the low range the contrabassoon) ... the tone itself, a kind of ghostly breath, truly has something ethereal in its nature, and easily moves certain susceptible minds with its gentle sounds. ${ }^{64}$

Schilling compares the aeolodicon's timbre to various woodwind instruments, and comments on the instrument's crescendo and decrescendo effects. He further emphasises that its novel sounds have a special influence on certain sensitive psyches. The idea that particular sonic characteristics novel timbres combined with dynamic swelling - had a privileged access to the nerves can be traced back to the prototypes of early romantic ethereal sounds: the glass harmonica and the Aeolian harp. ${ }^{65}$ The harmonica had long been associated with a dangerous effect on the nerves, a link made notorious by Franz Mesmer's employment of the instrument in his magnetisations. $^{66}$

By contrast, the gently swelling tones of the Aeolian harp, a set of strings stretched over a resonating board and brought into sound by the action of the wind alone, were frequently regarded as the benign resonance of nature or the Weltgeist. ${ }^{67}$ Through a complex series of relays between physicians, scientists, philosophers and poets, the Aeolian harp became a popular symbol of subjectivity in early romantic aesthetics. ${ }^{68}$ The aeolodicon was widely understood to inherit some of the Aeolian harp's ethereal sonic

writing this article I was not yet aware of Schneider's plagiarism, and discuss his case study alongside other medical reports.

63 For more on the emergence of free reeds and harmonium instruments in Germany see Jackson 2006. See also Orde-Hume 1986; Ahrens and Klinke 1996; Gellerman 1996.

64 Schilling 1834, 1:75, as quoted in Schneider 1835, 2:266. ${ }^{65}$ Dolan 2008, 13.

66 This connection may have originated in the effects of the lead used in the manufacture of the harmonica's forerunners, musical glasses. See Hadlock 2000, 525; Finger and Gallo 2004, 226.

67 See Abrams 1971, 51.

${ }^{68}$ As literary scholar Shelley Trower observes, the Aeolian harp provided at once 'a model for a human mind/body conceived as a machine for translating sensory vibrations into consciousness' as well as a metaphor for the artistic process of inspiration by 'transforming the force of the wind into harmonious sounds'. Trower 2012, 13. 
qualities, in particular its ability to gradually swell into sound. ${ }^{69}$ This sonic similarity was discussed by a number of nineteenth-century musicians, and enthusiastically promoted by harmonium builders, who gave their creations names such as aeolharmonica, aeolophon and aeolomusicon. ${ }^{70}$

Adhering to early romantic tropes of sonic ethereality, Schneider's description of Lina's response to the aeolodicon foregrounds her embodied attunement to its swelling effects. He begins his improvisation by gradually 'swelling to the strongest fortissimo, and then decreasing to a moderate piano', and starts the chorale, 'swelling from the lightest breaths and back again'. Lina entrains herself accordingly: 'at the beginning of the third crescendo and then immediately after [there] began a deep intake of breath and a strong shiver; that is, a complete seizure of the full nervous system'. ${ }^{71}$ While opera clearly defines Lina's illness, it also appears to inform her cure. Having lost her heart and mind to the suggestive sounds of love arias, she regains her health to the ethereal tones of religious music performed in an expressly theatrical context.

In the second case history, Schneider likewise employs a number of theatrical parameters to amplify the effect of music upon his patient's mind and body. These include repertoire, instrumentation, staging and dance. Notable here is the choice of the German song, which has four verses, in which a sailor bids his sweetheart farewell as he sets off on his ship, bemoans their parting, and outlines the pleasures and dangers of seafaring life. ${ }^{72}$ As in Lina's case, the selection of repertoire stands in a close relationship to Bals's circumstances, though in this case it is motivational rather than biographical. 'Matrosen' is a work song, and the sailor must leave his wife and go to sea in order to recover his mental health. It is aspirational in other aspects as well. Bals is consumed by 'an exaggerated fear of the future'. ${ }^{73}$ By cheerfully celebrating the risk inherent in a seafaring career, this song encourages the patient to return to work by placing his morbid fears into perspective.

Schneider informs us that the quality of the performance was excellent, as 'the street musicians of this harbour town take care to perform this sailor's ditty exceptionally well'. ${ }^{74}$ Like the refined domestic music that characterised Lina's treatment, these performers come from Bals's own social milieu. Schneider emphasises this by calling them Musikanten rather than Musiker, and specifying that they are street musicians, or

\footnotetext{
69 See Raz 2014, 115-44.

71 Schneider 1835, 2:267.

74 Schneider 1835, 2:291.

70 Notable here is Gleichmann 1820; see also Dodd 1853.

${ }^{72}$ W. Gerhard 1826, 1:143. ${ }^{73}$ Schneider 1835, 2:288.
} 
Schnurranten. Finally, he compounds the theatrical elements of the cure by specifying that the music causes the man to violently jerk his body and limbs, almost as if he were performing a St Vitus dance or tarantella. This bodily response to music is swiftly converted into a furious waltz followed by a physical collapse.

Both of Schneider's cures are highly theatrical. In the case of Lina, the musicians themselves are hidden, but the drama is implied through the allocation of vocal parts supported by a specific repertoire and instrumentation. This play-within-a-play induces a dramatic response from the patient, who herself is being observed by a proxy of her physician. Likewise, Bals is at first a spectator, observing his colleagues singing and the musicians playing. Observing this theatrical representation of his former life as a sailor ignites his desire to return to worldly pleasures, and he soon joins in as a participant, leaving his sickbed to dance with his wife and friends.

It is illuminating to compare Schneider's approach to opera with those of his (unattributed) sources. In his System der höhern Heilkunde (1826), the very volume from which Schneider lifts his case studies, de Valenti proposes that young men aspiring to good physical health avoid 'painted women and maggoty hothouse fruits, Ovid's artem amandi and Homer's accounts of Jupiter's flirtations, as well as bravura arias from well-known operas'. ${ }^{75}$ De Valenti's Medicina clerica (1831), a practical companion volume to System der höhern Heilkunde, offers a similar critique. Writing for a clerical audience, de Valenti describes how a complete village descends into sin after opening an amateur theatre. The pastor is complicit, and his daughter even lends the 'prima donna' her outfit for a comedy. ${ }^{76}$ This secular fall culminates in the introduction of operas, a 'monstrosity that the government promptly shut down'. ${ }^{77}$

Schneider appears to have a complex relationship to de Valenti. He writes at length about the importance of religion in conjunction with medicine, and repeatedly declares his intention to produce his own book on the pastoral care of the mentally ill. He also seems to regard System der höhern Heilkunde as a model, writing that of the approximately fifteen extant works dealing with pastoral medicine, only de Valenti's had any value. ${ }^{78}$ He may even have based his title page affiliation, 'der Philosophie und Musik Doktor' (the doctor of philosophy and music), on de Valenti's

\footnotetext{
75 de Valenti 1826, 1:150. $\quad{ }^{76}$ de Valenti 1831, 256. $\quad{ }^{77}$ de Valenti 1831, 257.

78 Schneider 1835, 2:372.
} 
signature of 'der Philosophie und Medizin Doctor' (the doctor of philosophy and medicine).

Given Schneider's respect for de Valenti and the cause of pastoral care, we might regard his decision to plagiarise these case histories as an act of appreciative criticism. Lacking any formal training in medicine himself, he was surely reluctant to simply fabricate medical details. The act of inserting himself into de Valenti's cases represents something of a fantasy of authority. Moreover, in rewriting his text and imagining how music might have played a positive role in the healing process, Schneider undercuts his role model's dismissal of music, and of opera in particular. Yet this revision is only partial: Lina loses her heart to the very same 'bravura arias' that de Valenti deplored, and regains her health through the wholesome sounds of a religious chorale performed within the family domicile.

\section{Conclusion: Between Therapy and Pathology}

Schneider's fictional case histories suggest that the author himself held conflicting views about opera. His musical cures adhere to Reil's and Pinel's theories regarding the importance of role-playing, and appear to support theatrical interventions in the treatment of mental illness. Moreover, his depictions revel in operatic clichés such as star-crossed lovers, melancholy, murder, guilt and ethereal sounds as well as the curative potential of staging and role-play. On the other hand, his explicit alignment of opera arias and recitative with sickness, and religious music and work songs with health suggest that he believed - or thought that his readers believed - that opera had a deleterious effect on health. Schneider's theatrical interventions are therefore especially designed to enact the transformation of opera into other genres: in Lina's case, Antonio's arias are supplanted by a four-part chorale, while Bals's ghastly recitative is replaced with a familiar sea shanty. The author's conflicted attitude is further evident in his decision to plagiarise and subvert de Valenti, a religious physician who was pointedly opposed to opera in all forms.

This ambiguous conception of opera is mirrored in System einer medizinischen Musik. Schneider time and again states that music is a healing medium; but while he treats church, chamber and concert music at length, opera is almost entirely excluded from discussion. Schneider devotes only six pages to 'theatrical music', in which he repeatedly states that opera is harmless. He maintains that while operas do not serve a morally edifying purpose, they cannot corrupt children or the 'pure of heart'. Moreover, he 
argues that they are no worse than plays for adults and adolescents. ${ }^{79}$ In support of this claim, he cites Markus Herz's 1797 case history of a female amnesiac who had forgotten attending a performance of Die Zauberflöte. ${ }^{80}$ Once recovered, Herz notes, she held the unusual distinction of having enjoyed the opera for the first time on two separate occasions.

It is no coincidence that Schneider's anecdote regarding opera was nearly four decades old by 1835 , as it was actually plagiarised from the Viennese physician Peter Lichtenthal's influential book on music therapy, Der musikalische Arzt (The Musical Doctor; 1807). ${ }^{81}$ Schneider's treatment of opera borrows heavily from Lichtenthal's corresponding chapter, lifting many passages verbatim and paraphrasing others without attribution. However, as in his other plagiarisms, there is a crucial difference: Lichtenthal has no concerns about potential dangers inherent in opera, and enthuses about Die Zauberflöte, which he claims to have seen ninetythree times. He further praises the genre of opera for affording a truly magical variety of characters, emotions, scenes and impressions. ${ }^{82}$ Having excised Lichtenthal's operatic effusions, Schneider's attempt at defending opera from its detractors appears to be fully his own.

It seems the plagiarism in System einer medizinischen Musik was never discovered, and the book garnered positive attention from the musical community. The Allgemeine musikalische Zeitung (1835) commended the author for his diligence in compiling abundant source material, ${ }^{83}$ and the Allgemeiner musikalischer Anzeiger (1836) praised it as a 'significant summation of original and varied insights, historical discoveries and testimonies, and factual compilation'. ${ }^{84}$ In his annotated bibliography Systematisch-chronologische Darstellung der musikalischen Literatur (1839), Carl Ferdinand Becker commented on Schneider's erudition and evident love for his subject matter. ${ }^{85}$ An entry in the Musikalisches Conversationslexikon of 1840 celebrated the author's multifaceted scholarship and set high expectations for his future. ${ }^{86}$ This was a poignant note, given that Schneider had died three years earlier at the age of twenty-seven, poisoned by his assistant, who committed suicide shortly after. ${ }^{87}$

The ethics of inventing medical case histories notwithstanding, Schneider's reports make significant innovations in theorising the affective treatment of the causes behind mental illness. First of all, unlike the exoneration of Pinel's patient in a mock trial, Lina and Bals are not

\footnotetext{
79 Schneider 1835, 1:236-7. $\quad{ }^{80}$ See Herz 1798. $\quad{ }^{81}$ Lichtenthal 1807, 69.

82 Lichtenthal 1807, 66-7 ${ }^{83}$ [unsigned] 1835, 779. ${ }^{84}$ [unsigned] 1836, 65.

${ }^{85}$ Becker 1839, 8. ${ }^{86}$ [unsigned] 1840, 407. ${ }^{87}$ Henseler 1959, 119.
} 
dosed with a fraudulent reality manufactured to suit their pathology; music is used to suggest rather than replace. De Valenti's cures result through chemical means: the melancholy girl is simply treated with a powerful emetic. By contrast, Schneider replaces de Valenti's methods with staged performances of music, which targets his patients' minds and bodies through sonorous vibrations.

In featuring music rather than words, Schneider's case histories exemplify how sound can permit direct access to the unconscious by reconfiguring the musical and musically inspired symptoms of mental illness into symbolic communication to be treated on its own terms - that is, by music. This idea of 'symptom as symbol' prefigures ideas about hysteria that would be developed by psychoanalysts over fifty years later. This step is original to Schneider, and is nowhere to be found in de Valenti, Schreger or his other sources. The tension manifested between Schneider's own operatic imagination and medical ideas about the genre's potential dangers reveals a transitional moment in which opera was simultaneously correlated with sickness and health in the early romantic imagination. 